\title{
HISTORICAL REVIEW OF MAHALAXMI MUNICIPALITY: AN INTEGRATED DEVELOPMENT PERSPECTIVE
}

Badal, B. P. ${ }^{2}$

\begin{abstract}
The history of Mahalaxmi Municipality is starting from Ramayana era, so it is completely a historical settlement, sets back to the timeline of 5000 BC. Archeology Department of Government of Nepal had explored the place and found the symbols of stone age weapons here in Lubhu. Shringi Rishi, who organized the Putresthi Yagya (Embryological Treatment) to give the birth of Ram Laxman - the God, sons of King Dasharath of Ayodhya, India, was born in Lankuri Bhanjyang of the Municipality. Typical Newari settlements of Lubhu and Siddhipur have unique history and culture - completely different from other Newar of Kathmandu Valley. The most beautiful land like gold of Ganga Maharani is Called Lubhu in Newari. Culturally Buddhists philosophy of Nalanika Jatak is also associated with the holy land of Serang or Shringi Rishi. The study is based on personal observation, review of old literatures, and Tourism Master Plan 2017 of the municipality.
\end{abstract}

Keywords: Culture, History, Mahalaxmi Municipality,

\section{Background}

Mahalaxmi Municipality (MM) is a historic town of Lalitpur District formed by integrating four historic villages i.e. Shringasram Lamatar, Rural Textile City with Mahalaxmi temple Lubhu, small and beautiful typical Newari settlement Siddhipur, Land of Tikeswor and Painachal Mahadev Tikathali and Land of Pearls -Motitaar Imadol. Mahalaxmi Municipality is natural unification of Lamatar, Lubhu, Siddipur, Tikathali and Imadol VDCs of Lalitpur. It is located in South West part of Kathmandu valley and in six-kilometer distance from Tribhuvan International Airport. Rayale Kushadevi of Kavre district is in east, Lalitpur metro City is in west, Godawari Municipality of Lalitpur is in South and Kathamndu Metropolitan City of Kathmandu, Madhyapur and Suryabinayak Municipalities are situated in North side of Mahalaxmi Municipality.

2 Dr. Badal is a visiting lecturer of Rural Development in Central Department of Rural Development, Tribhuvan University and Head of Research Nepal. Email: bpb222@ yahoo.com 
Among those five villages Lankuri Bhanjyang is situated in eastern hills of Lamatar village with stunning view of High Himalayan Range is outstandingly emerging tourism hub for youngsters. It is also renowned as Nagarkot of Lalitpur. Rishaal Danda, Ganeshman Singh Memorial Park, Resort Area, Army Area, Shringeri Cave, Manamohan Memorial View Tower, Kamadhenu Cave, Suremaite Cave, Daregaunda and Kot Danda are collectively united as Lankuri Bhanjyang as a significant tourism destination of Mahalaxmi Municipality (Mahalaxmi Municipality, 2072). These places are naturally very beautiful and people can view sunrise and famous majestic snowcapped mountains like Mt. Ganesh, Mt, Gaurishankar, Mt. Manasulu and some western part of Mt. Everest including entire Kathmandu Valley. The stunning beauty of natural Jungles, birds, down valley, high Himalayan Mountains and wonderful culture attract and make everyone to spend their whole life here.

Mahalaxmi Municipality is located at Southeast of Kathmandu Valley. The Municipality has occupied 26.5 sq.km. Total population of Municipality is 62172 in 14930 household with 31,071 male and 31,101 females. Average household size is 4.26 Person. Population distribution among different age group show that majority of population is between 15-59 Years (Mahalaxmi Municipality, 2072)

Literacy rate of the Municipality is $82.1 \%$ of which $90.9 \%$ of male are literate whereas only 73.4\% female are literate. Mahalaxmi Municipality caters two Traditional cities Lubhu (about 9 ha) and Siddhipur (about 5.3ha). Majority of Population are Newars followed by Chettri, Bhramin Tamang, and others. Being traditional Newari settlements, more than 80 $\%$ in Siddhipur and more than 50\% in Lubhu are Newars. Majority of Population in Imadol and Tikhathali are Chhetree whereas in Lamatar, Chhetri and Brahman are found almost equal in number (Mahalaxmi Municipality, 2072). 65\% of land is in constraint free area, so, there is space for development (Mahalaxmi Municipality, 2072). The practical tourism campaign can easily transform the society with people's social welfare motive (Shakya, 2008). People must be involved with the feelings of social welfare in the development of Tourism of the places.

\section{Objective and Methodology}

The main objective of the study is to explore the socio-cultural bases of development 
of Mahalaxmi Municipality. Thus, the study has identified the projects of sustainable tourism development of the municipality. Methodologically the researcher has visited entire 10 wards, observed and analyzed the previous plans. Reviewed the tourism master plan and found out the plans and listed.

\section{Discussion and Analysis}

History

Lubhu is traditional economic hub of textile industry; it is typical Newari cultural and archaeological town. It needs intensive research and exploration. So, the Municipality has to invite different universities, scholars and students for research activities. Archeological department has identified the place as the most. Archaeological explorations indicate that Kathmandu and the two other sister towns in the valley were the oldest towns and are traced to the period between $167 \mathrm{BC}$ and $1 \mathrm{AD}$. Excavations conducted at Handigaon and Lubhu in southern part of the valley, in Kathmandu, have unearthed brick walls and Stone Age tools.

Rishya Shringa the Grandson of Kashyap Buddha and son of sage Bibhandak was also a famous sage Bodhisattaw of the time. At this time penance of sage Shringa, Sakkaking of heaven was frightened and to break penance of the sage he had sent a nymph (Urbashi) in Shringa Rishi's Ashram. The nymph was called as Nalanika. She had very long discussion with Risya Sringa about love, relation and importance of family. The discussion is called Nalanika Jatak in Buddhist philosophy. But Shringa Rishi was very strong in his values and ideologies. She was not able to break his penance so in Buddha's age, she became Yasodhara -Spouse of Lord Buddha. The story has justified the proverb "The facts never fade out". Therefore, Lakuri Bhanjyang is equally important for both Hindu and Buddhist all over the world. India has claimed the place is in India but now it is proved that the birth place of Rishi Shringa lies in Lankuri Bhanjyang of Mahalaxmi Municipality, Lalitpur, Nepal. Although he was popular all over the south Asia in that era.

Around the era of King Dasharatha of Ahyodhya in 5000 BC Rishi Bibhandak used to live with a Kamdhenu cow (a special God Cow who cares devotees) in the jungle around Lankuri Bhanjyang. Every day they used to visit Pashupatinath to offer the milk of Kamdhenu cow from the route of Lubhu. God Pashupatinath was very happy and 
was blessed by Pashupatinath. Indra the King of Heaven was jealous from the Rishi Bibhandak so he sent Apsara Urvashi to break his devotion in the disguised form of Doe. She was successful to grab him in him in love trap and gave a birth to Shringa Rishi. After completion of her task she returned back to Heaven leaving the child and Bibhandak also left the child with The Kamadhenu Cow (Paudel, 2016). Actually, Bibhandak was spermologist and expert of Trans-fertilization. So, he has used his own sperm to the doe's womb.

Shringa was born from doe had a kind of horn on his head and used to play as a dear with lot other deer and birds in his childhood. Mother cow Kamadhenu was his patron. One day when she was in the way to Pashupati thought to rest few minutes but got on deep sleep. When she woke up it was very late and she was in very hurry she let her dong suddenly. From that dong Shringa Rishi had made a Shiva Lingam but a beautiful Shiva Lingam erupted itself. This Shivalinga became very famous as Govrateswor Mahadev in Lubhu (Ghimire R. , 2016). The fact is based on Skandapuran, Himawatkhanda, Nepal Mahatmya according to him.

So historically Shringa Rishi was born and had meditated here in the Shringasram Temple that it used to be a cave. The ancestry of Shringa Rishi is Kasyap Rishi so all the Kasyap Gotriya linage has to worship Shringa Rishi. He was the inventor of Putresthi Yagyna (The Vedic Ceremonial Rite to beget child from Male Progeny). He had visited Ayodhya in $5000 \mathrm{BCE}$ with the invitation of King Dasharath to organize the Putresthi Yegya for him to get sons.

" Ram was and is for real. He was born on January 10, 5114 BC". It was on February 18, $3102 \mathrm{BC}$ that Krishna breathed his last breath. The earliest evidence of the temple's existence dates back to 400 A.D. The current main temple of Pashupatinath complex was built in the end of the 17 th century to replace the previous one, destroyed by termites.

From his noble work lord Ram and his brothers were born. Still the people from all around the world visit the small temple to get child or their prosperity (Ghimire J. , 2015). He had visited and Meditated and served some putresthi yagyas in Resunga hill of Gulmi district also. From the name of Sgringa Rishi the place was named as Shringasram and finally it became Shringeri and Sisnery. 
We have Sisneri Higher Secondary School and Shringeri High School is running in the memory of Shringa Rishi. Later on, with the fame and reputation of Shringa Rishi people had built a small temple of Ram on long terrain land (Taar). The place began to call Ramtaar and finally it became Lamatar in the tongue of Local People. Finally, he married with so called sister of God Ram called Shanti and began to live in India. They had many sons (Ghimire J. , 2015). The God Mahadev originated by the Gobar (dong) of Kamadhenu Cow became famous as Govrateswor Mahadev in Lubhu (Rishi, 4 BC). Lubhu was the religious settlement of Goddess Mahalaxmi and Mahabhairav main clan deity (Kul Devata) of Newar Community. The city was once ruled by Queen Ganga Rani -wife of king Shiva Singh Malla of Patan. She had sold her golden plate and made a Big Pandal with golden roof to preserve and care sick people of the place. So, it is also called Swrna Chhatrapur. In typical Newari language Lubhu is Golden Plate. The golden plate settlement (Lubhu) was centrally preserved by Mahalaxmi and her temple is in Centre of the settlement (Paudel, 2016). Due to the blessing of Goddess Mahalaxmi this municipality is also named as "Mahalaxmi Municipality".

The municipality has formed a tourism and social development subcommittee (Mahalaxmi Municipality, 2072). The first Council meeting of the Municipality has identified and declared the Beautiful Natural sites from where we can view entire Himalayan range of Kathmandu Valley - Lanmuri Bhanjyang a complete tourist's destination. Municipality has given more impetus to Lankuri Bhanjyang. Lankuri Bhanjyang is beautiful stunning scenic place with cultural values of Rishi Shringi and Buddism. The place is developing according as the playing Garden of Rishi Kasyap, Bibhandak and Shringa with Apsaras and Urvashis. All the Khonch or low lands are being developing as the beautiful lakes and ponds with beautiful hotels, bars and so on. Probable development projects are listed in following table 
(Destinations of Development in Mahalaxmi Municipality)

\begin{tabular}{|c|c|c|c|}
\hline Ward & Location & Description & Probable projects \\
\hline 10 & $\begin{array}{l}\text { Mane } \\
\text { Dobhan } \\
\text { / Lankuri } \\
\text { Bhanjyang }\end{array}$ & $\begin{array}{l}\text { Halichaur stupa, Bhimsen } \\
\text { Danda, Lamadanda Mandir, } \\
\text { Fulchoki temple, Kalidevi } \\
\text { temple, Sringa Rishi cave, } \\
\text { Julia baas, Daregaunda, } \\
\text { Suremaite Cave, Manamohan } \\
\text { View tower, Ganeshman } \\
\text { Park, Hotel of Ang Chhiring } \\
\text { Sherpa, Land of Rameshor } \\
\text { Thapa, Bikash Ran, } \\
\text { Bashanta Mishra }\end{array}$ & $\begin{array}{l}\text { Halichaur Mane Punyatama } \\
\text { River trekking trail } \\
\text { Lattha Bhanjyang Ranikot Road } \\
\text { Pokhari ThumkoVibhandaklake } \\
\text { park } \\
\text { Bhanjyang Shringi Lake Garden } \\
\text { Daaregaunda Lankuri Motor } \\
\text { Road } \\
\text { Biggest Statue of Shringi Rishi } \\
\text { Trout fish Municipality park } \\
\text { Ramayan Circuit from Shrigi } \\
\text { Apsara park (Angel's Park) } \\
\text { Tamang's Home stay }\end{array}$ \\
\hline 9 & $\begin{array}{l}\text { Lamatar, } \\
\text { Dhungin, }\end{array}$ & $\begin{array}{l}\text { Gomati River, Sringamati } \\
\text { River } \\
\text { Mahalaxmi, Devisthan } \\
\text { Chaur, P a nd a li pakha, } \\
\text { Dhyakedanada, Paudeldhara, } \\
\text { Dhungen, Sisneri Baiseri, } \\
\text { Daregaunda, Ghaderi Bus } \\
\text { Park } \\
\text { Aaitabare picnic spot } \\
\text { Dhungedhara, Sisne } \\
\text { Dhara, Mula Dhara, Kaal } \\
\text { Dhara, Pipal Dhara Mathlo } \\
\text { Ganessthan, tallo }\end{array}$ & $\begin{array}{l}\text { Shringamati river trekking } \\
\text { Gomati River Trekking } \\
\text { Bird-Butterfly study center } \\
\text { Sisneri, Shringi, Juliabas Gomati } \\
\text { deer } \\
\text { Thakurigaun, kot, Aitabare } \\
\text { Dharachaur Rainbow trekking } \\
\text { steps } \\
\text { Kot Museum, Eco Energy park } \\
\text { Health clubs (Sports Centre) } \\
\text { Brahman's Home stay } \\
\text { Aitabare Picnic Spots } \\
\text { 1000 steps for Rainbow trek } \\
\text { ThakuriGaun Jyamirkot Deer } \\
\text { Walk, Stone taps observation } \\
\text { route }\end{array}$ \\
\hline
\end{tabular}




\begin{tabular}{|c|c|c|c|}
\hline 9 & $\begin{array}{l}\text { Sisneri } \\
\text { Aarubot } \\
\text { Jyagata } \\
\text { Lamatar, } \\
\text { Bhujunge, } \\
\text { Sasambhu }\end{array}$ & $\begin{array}{l}\text { Ganeshthan, } \\
\text { Ganessthan, } \\
\text { Ganesthan } \\
\text { Biswamitra, Gochandeswori } \\
\text { Dandathok Bandebi, } \\
\text { Shiddeswor, Daanti devi, } \\
\text { Kirant Falgunanda's temple } \\
\text { Ramchandra Mandir, } \\
\text { Sasambhu Devi, Naagsthan, } \\
\text { Panchayan Mandir and } \\
\text { Kriyaputri Sattal, Pathak } \\
\text { Chaur, sasambhu Chaur, }\end{array}$ & $\begin{array}{l}\text { Suremaite cave on Dantikoban } \\
\text { Temple Link Trail } \\
\text { Chakramati Trekking Route } \\
\text { Fulbaari Park } \\
\text { Pandali Pakha patiko Chaur } \\
\text { Rana Magar Home stay } \\
\text { Hill top Recreation Centers } \\
\text { Children's Fun Park } \\
\text { Sasmbhu sports center } \\
\text { Sasambhu, Devisthan, Lamatar } \\
\text { Park } \\
\text { Textile Business Club } \\
\text { Real Estate Business Club }\end{array}$ \\
\hline 8,7 & $\begin{array}{l}\text { Lubhu } \\
\text { Chasidol } \\
\text { Godawari } \\
\text { Khola } \\
\text { Lubhu } \\
\text { Lubhu }\end{array}$ & $\begin{array}{l}\text { Mahadevsthan, pingan } \\
\text { Mandir, somlingeswor } \\
\text { Sankhadebi, Bisundol } \\
\text { Nepalchaur, Bhotini Chaur, } \\
\text { Mahalaxmi, Devisthan, } \\
\text { Bihar, Govrateswor, } \\
\text { Suwarneswor, Vajan Guthi, } \\
\text { Saaibaba mandir nirman, } \\
\text { Bhairab sthan, Gorakh naath } \\
\text { Nasal chouk, pati, pokhari } \\
\text { Kot Ghar, Khashi Budhha } \\
\text { Mandir, Tagatun Nasal, } \\
\text { Nasal chouk, pati, pokhari }\end{array}$ & $\begin{array}{l}\text { Lubhu Heritage Walk } \\
\text { Mahalaxmi Pilgrimage Tour } \\
\text { Textile factory observation route } \\
\text { Anthropology Research Centre } \\
\text { Newa Research Centre } \\
\text { Living Culture preservation } \\
\text { Gift item production of Textile } \\
\text { Every home is home stay } \\
\text { Godawari Riverside Trekking } \\
\text { park satsang asram, } \\
\text { Bishnudol Tower, } \\
\text { Jyamirkot View } \\
\text { Falgunanda Children Falgunanda } \\
\text { Nepal Chaur Lubhu, Siddipur } \\
\text { Bisnudol to Falgunanda dharma } \\
\text { trek }\end{array}$ \\
\hline
\end{tabular}




\begin{tabular}{|c|c|c|c|}
\hline 5 & $\begin{array}{l}\text { Tikathali } \\
\text { Changathali }\end{array}$ & $\begin{array}{l}\text { Bhimsen Mandir, Siddeswor } \\
\text { mandir } \\
\text { Moteswor, Tripur samaj } \\
\text { sudhar, Jhikucha Bhagabati, } \\
\text { Udayabinayak } \\
\text { Gupteswor } \\
\text { Buddha Bihar } \\
\text { Satchitananda Asram } \\
\text { Godawari River } \\
\text { Laakhe culture }\end{array}$ & $\begin{array}{l}\text { Home stay } \\
\text { Temple link trekking Route } \\
\text { Children park } \\
\text { Heritage walks } \\
\text { Newari Pub } \\
\text { Live Jatra Theater } \\
\text { Business Hotel } \\
\text { Newari Food Court } \\
\text { Panchakanya } \\
\text { Narkate Siva mandir }\end{array}$ \\
\hline 6 & Siddipur & $\begin{array}{l}\text { Kotghar, Ganesh, Bhairab, } \\
\text { Krishna and Baalkumari } \\
\text { temples, Buddha Bihar park, } \\
\text { ponds and Parks } \\
\text { Kot ghar, Bhairab Mandir, } \\
\text { Siddeswor, Siuro khya: two } \\
\text { Buddha Pokhari } \\
\text { Chihan Danda } \\
\text { Shantipokhari, } \\
\text { Satya pokhari }\end{array}$ & $\begin{array}{l}\text { Home stay } \\
\text { Temple link trekking Route } \\
\text { Children park } \\
\text { Heritage walks } \\
\text { Newari Pub } \\
\text { Live Jatra Theater } \\
\text { Suku Museum } \\
\text { Newari Food Court } \\
\text { Kot - Thasi Museum } \\
\text { Bakhu Mahadeb }\end{array}$ \\
\hline $\begin{array}{l}1,2, \\
3,4\end{array}$ & $\begin{array}{l}\text { Imadol } \\
\text { Kist Hospital } \\
\text { Bojhe } \\
\text { Pokhari } \\
\text { Gwarko } \\
\text { Kamal } \\
\text { pokhari }\end{array}$ & $\begin{array}{l}\text { Sarbeswor Sita mandir } \\
\text { Radhakrishna pranami } \\
\text { mandir, Mahadev, Karnaali } \\
\text { height Gumba } \\
\text { Basuki, Durga, Pashupati, } \\
\text { Kotghar } \\
\text { Painachal Mandir, Indreswor, } \\
\text { Bhagawati, Narayan Mandir } \\
\text { Ashok Stupa, } \\
\text { Bhagwansthan, Gnesthan } \\
\text { Manakamana Bojhe Pokhari, } \\
\text { Manohara River }\end{array}$ & $\begin{array}{l}\text { Setipakha Park, Energy Park } \\
\text { Radhakrishna pranami mandir } \\
\text { Karnaali height Gumba spiritual } \\
\text { Park } \\
\text { Children Park, Kot Ghar Museum } \\
\text { Temple walk route } \\
\text { Tourism Development Fund } \\
\text { River Side } \\
\text { Manohara Evening Energy Park } \\
\text { Bojhepokhari Fishing Park } \\
\text { Samrat Ashok Bippasana Centre } \\
\text { River side Trekking Route } \\
\text { Kamal Pokhari Park } \\
\text { Laliteswor Park } \\
\text { Mankamana Temple Park }\end{array}$ \\
\hline
\end{tabular}

(Tourism Master Plan, 2016) 
Therefore, local government of Mahalaxmi Municipality has to address the above stated plans and projects for sustainable development.

\section{Culture}

Mahalaxmi Municipality is the garden of different god and goddess. Symbol of Lord Buddha "Ashok Stupa" - Thur of Mahalaxmi Municipality - 1 is standing on the entrance to welcome the visitors. The Stupa is the symbol of Buddha's discourse and philosophy. According as the philosophy of Lord Buddha "Life if full of misery, there are the causes of miseries, and there is the solution of every human misery". The stupa development committee can organize different meditation camps for devotee pilgrims. Bowing with respect "Bhawatu Sabba Mangalam" the alternate parallel highway of Araniko Highway - "Mahalaxmi Highway" reaches on Radha Krishna Pranami Mandir. It is only one character of Mahabharat who had taught Shrimad Bhagwat Gita to Arjuna. The Gita is the finest summary of entire knowledge of Veda, Purana and Upanishads the great epics of Indus Civilization. Only the Krishna -Virata Swarup of God is situated in Krishna Mandir of Imadol. "Offer your work (Karma) to worship god. The temple of love and devotion is the only one Nawatan Puri Dham of Nepal where Raji Krishna Dwells. This is the greatest temple of Krishna pranami community of Nepal.

From the Krishna Pranami Mandir across 300-meter distance, close to a big tree called Khariko bot, there is a small Masjid of Muslims. As a secular country Nepal, Nepalese Constitution approves the Muslims of Nepal represents the minority group having $6 \%$ of total population. The origin of Islam can be traced back to 7th century Saudi Arabia. Islam is thus the youngest of the great world religions. The prophet Muhammad (circa 570-632 A.D.) introduced Islam in 610 A.D. after experiencing what he claimed to be an angelic visitation. Muhammad dictated the Qur'an, the holy book of Islam, which Muslims believe to be the preexistent, perfect words of Allah.

The invasion of Nepal Mandala by Shamsuddin Ilyas, the Sultan of Bengal on November 19, 1349 was the interesting story of entry of Nepalese Newari Muslim. It is described in the contemporary record that in N.S.470 on Marga Sukla Navami (November 19, 1349 A.D.) Sultan Shamsuddin entered (the valley) and set everything on fire for seven consecutive days. Sultan Shamsuddin not only set the three towns of the valley to fire, he also broke the Pashupati phallus into three pieces and completely destroyed the 28 
Swayambhu Chaitya and other temples and Viharas in the valley (Vaidya, 2001). The sultan did not stay more than seven days in valley but among from their troops some of Muslims are respectfully preserved in Lalitpur by Malla kings. The Newari Muslims of Lalitpur follow both cultures. Islam is the religion of peace and mercy.

Just crossing the Masjid there is a beautiful pond of Lotus. It was just a normal pond and people started to preserve it with planting the seeds of Kamal. Lotus is the symbol of peace and chair of Lord Buddha in Buddhism. It is a symbol of tender delicate love and beauty in Hinduism. Brahma had seated in a Kamal and created the universe. The municipality has to erect a pillar in mid of the pond with Kamal and Brahma. Trees and surroundings of Laliteswor Mahadev temple should be developed as a natural green park for city dwellers. All these small shrines or temples may attract the tourists for mini researches.

Crossing the wonderful mini park of Kamalpokhari, we reach a beautiful cultural village called Siddipur -the village of Salvation. Now Siddipur is a town with rich Newari culture with Hindu and Buddhists mix society. The city is famous for hay arts. Traditional houses are destroyed by the devastating earthquake of 2015 . Now the municipality has to develop a building code of conduct for reconstruction. The reconstruction must be able to preserve the traditional cultural identity of the area. We must preserve the lost heritages. Many temple and mosques have to be rejuvenated.

The temples, mosques, shrines, streets pond etc. inside the Siddhipur should be joined as heritage walk route. The traditional Newari community should be trained for tourism, homestay and hospitality. The streets should have scientific homestay facilities, cultural guides, and tourists' friendly cultural festivals. They should be also trained for common popular food preparation for tourists around the globe. So, Municipality has to form a cultural tourism subcommittee, make heritage walk route and notice information boards. Kot Ghars (Forts) should be developed as museum. Temple and mosques should be developed as the symbol of love respect and coexistence of Hindus and Buddhists. The subcommittee will preserve the cultural icons and coordinate municipality and other stakeholders to develop the years old culture and history.

We die therefore our life is beautiful. The death is beautiful universal truth. When we 
see the funeral, we think about our life. It is true we have to leave all our relatives and property. Forgetting the reality, we are hunting adulthood and wealth as we never die. Yes, we have to work today as we will die tomorrow. To learn the facts of death and life Siuro kya (Death Tomb) of Buddhists and Godawari Ghat of Hindus will be the best place. Dead bodies are set in fire there. It is the philosophy of end. So, it should be developed as the short-term school of death rituals of Hindus and Buddhists. Tourists can view death rituals and cultural traits. Municipality has to make such places tourists friendly that caring the psychology of people in funeral. Tourists watching and resting places should be developed there either side of river and Chihan Danda.

Godawri River is the replica of Biggest Godawari River of India. People who cannot visit Godawari to take a holy bath have to come here for salvation and emancipation from all kinds of sins. Municipality has to motivate Kantipur Engineering Collage and Donbosco School to develop a tourist friendly pool and taps for holy bath.

After crossing the Godawari river tourists find wonderful traditional cultural textile town called Lubhu. Lubhu is literally a Golden Plate in Newari Language. Ancient Ganga Maharani had established the settlement by selling her golden plate or she might have occupied the land like golden plate for paddy production. In Buddhists literature the place is also known as Suwarna Chhatrapur. We have a beautiful Suwarna Chhatrapur Vihar at Lubhu. The queen had installed a pandal with golden roof for the treatment of sick people. The city is also famous for traditional textile industry. Still there are hand looms in every household of Newar Community. It is very famous for different cultural festivals - Jatras. From the perspective of Religious Pilgrimage, the place is very important for buddists as well as Hindus. Suwarna Chhatrapur Bihar, Mahalaxmi temple, Mahabhairab, Devisthan, and Govrateswor temple are very popular and important historical monuments. From the name of Mahalaxmi Temple the municipality is named as Mahalaxmi Municipality.

Another very famous temple of God Bhairab is also located here although entire streets of the town are full of different temples. God Bhairab is the Kul Devata (Clan's Deity) of Newar Community. Bhairab is also the incarnation of Lord Shiva. In every Newari settlement we can view the temples of Bhairab, Balkumari, and Barahi Ajima for the blessing and rescue or betterment of clans and children. This is the main Bhairab (Chief Clan Deity) of Newar so every Newar has to visit the temple. The temple management 
committee has to revive this culture and make suitable homestay for entire Newari Community once in a year.

The Govrateswor Mahadev temple is another famous cultural heritage of Mahalaxmi Municipality has been inscribed in Skanda Purana has great history associated with Kamdhenu Cow, Pashupati and Shringa Rishi. The Shiva Lingam is one of Linga of 64 Lingas. Skandapuran, Himbatkhanda, Nepal Mahatmya birupaxya tirtha yatra: Goshringa Tritha ra Govrateswor Mahatyma 133 unit describes the story as follows.

Under the Hills of Chakranemi (hills from Anantalingeswor to Jyamirkot Bishankhu as a semicircle of rainbow) there is a temple of Govrateswor Mahadev where Birupaxa had visited and worshiped to Mahadev with Nemuni. Nepal has been named with the great contribution of the same sage or rishi Nemuni. The Birupaxya Brahman had taken holy bath on Shringa Tirtha (Confluences of Shringamati (Sisneri) and Gomati (River from Ghimire Gaun) Rivers at Lamatar of Ramtar Rammandir) had worshiped the Govrateswor on Chaitra Shukla Dwadashi. Birupaxya and Nemuni stayed a night and Nemuni had told the story to Birupaxya.

Many years back Shringa Rishi had taken the holy bath and saw the Kamdhenu returning to the Charanawat Cave (A cave in Bhimsen Danda) all of a sudden, she produced dong. Shringi Rishi held that dong and established a Shiva Linga. As it was developed from dong it is called Govrateswor. Again, there was a Newar with many sexual and skin disorder once had holy bath in Shringa Tirtha Tripundeswor and became fine came and worshipped Govrateswor. He received a lot of blessing, fame and charming on his entire body. Being happy he had offered a golden roof for the temple of Govratswor so the place is also known as Suwarna Chhatrapur (Himawatkhanda Bhasha pp 264).

In the top of Chndrawat Sirsasthali - top of the Municipality has to install massive statue (about 300-meter height with necessary base width having big conference hall) of Shringa Rishi that should be viewed from all around the Kathmandu valley and Kavre. They have to start special festival in Rishi Panchami. According as the Skandapuran, Shringa Rishi blesses for peace, progress and prosperity of Children and treats for complete safe motherhood and female mensuration. Elder People around the area believe that many women and men who were not being able to produce children had produced after the visit 
to the cave. If we have same cases we should go or send our people to worship the Shringa Rishi will be fruitful. All the Kasyap Gotriya people should be mobilized here to collect the fund and investment

Ecotourism can be considered as a subset of sustainable tourism and nature tourism because it represents a sustainable way of travelling in natural areas. Basically, Eco tourism is According to international processes, ecotourism should be replaced by the term sustainable tourism (Vrujci, 2005). So, ecotourism is sustainable tourism and it is also an economic method of tourism development. Ecotourism and its natural assets and raw materials to create, as well as directing people to travel is an attractive force (Role of Ecotourism in Sustainable Development, 2013). So cultural Areas like Lubhu and Siddipur River Basins of Karmanasha, Manahara, Hanumante, Godawari rivers; Forests of Sankhadevi to Ananataligeswor, top heights of hills, Lankuri Bhanjyang, punyatama, Gomati, Shringamati Riversides, are absolutely potential for ecotourism.

Specifically, Lakuri Bhangyang is located 13 kilometers, southern upwards from Kathmandu, resembling a little paradise. It is one of the most scenic spots in Lalitpur district and is renowned for its spectacular sunrise view and the Himalaya range. The view of the sunrise can be seen, almost up-close and draws several tourists here. Sitting in Lakuri, one can also see the cities of Kathmandu, Lalitpur and Bhaktapur. The environment is extremely clean, fresh air, cool water and lush green forests, topped with extremely friendly locals which in itself are an experience.so it is very potential place to be developed as a tourism destination of Mahalaxmi Municipality. We can attract big number of Indian Tourists to view the birth place of Rishi Shringa.

From the Buddhists perspective, Grandson of Kasyapa, son of Vibhandak sage Shringi Bodhisattwa, was seduced by Nalinika, nymph of King Sakka (Indra) previous existence of queen Yeshodhara, spouse of Gautam Buddha. So, the philosophy of Hindus and Buddhists coin together.

\section{Conclusion}

Mahalaxmi Municipality is the starting point of Ramayana, completely a historical settlement sets back to the history of 5000 BC. Archeology Department of Government of Nepal had explored the place and found the symbols of stone age weapons here in 
Lubhu. Shringi Rishi, who organized the Putresthi Yagya (Embryological Treatment) to give the birth of Ram Laxman - the God. Typical Newari settlement Lubhu and Siddhipur have unique history and culture - completely different from other Newar of Kathmandu Valley. The most beautiful land like gold of Ganga Maharani is Called Lubhu in Newari. In conclusion the settlement is appropriate for Religious, Cultural, and Eco-Tourism. The preservation is most and its advertisement will develop the tourism and livelihood of the people. For the governments it will be the useful documents for development projects.

\section{References}

Ghimire, J. (2015, February 2). Skandapuran, Himabatkhanda Nepal Mahatmya. (P. Madhav, Interviewer)

Ghimire, R. (2016, June 4). Tourism Master Plan. (B. Badal, Interviewer)

Mahalaxmi Municipality. (2072). Annual Municipal Development Plan 073/74. Imadol Lalitpur: Municipality.

Paudel, M. (2016, June 4). Tourism Master Plan. (B. Badal, Interviewer)

Rishi, S. (4 BC). Skandapuran Himawatkhanda Nepal Mahatmya. Kathmandu: Nepal.

Role of Ecotourism in Sustainable Development. (2013). In T. Kiper, Advances in Landscape Architecture (pp. 773 -802). Turky: Intechnamık Kemal University, Faculty of Fine Arts, Design and Architect, Department of Landscape.

Shakya, K. (2008). Tourism - Yesterday, Today and Tomorrow. In R. P. Upadhyaya, Readings in Rural Tourism (pp. 31-42). Kathmandu: Sunlight Publication.

Vaidya, T. (2001). Devaladevi, the de Facto Ruler of Nepal. Voice of History, Vol. XVI, No. 2 (Dec. 2001), 12-18.

Vrujci, B. (2005). What is ecotourism? -An introduction. Ecological Tourism in Europe, CEEWEB Academy. 